\title{
Value relevance of $R \& D$ in the UK after IFRS mandatory implementation
}

\author{
F. Tsoligkas ${ }^{\mathrm{a}, *}$ \\ and \\ I. Tsalavoutas ${ }^{\mathrm{b}}$
}

We thank the Accounting and Finance Division at The University of Stirling as well as the XFi Centre for Finance and Investment at The University of Exeter for funding access to Thomson One Banker and DataStream. We gratefully acknowledge helpful comments received from Paul André, Christina Dargenidou, Dionysia Dionysiou, Al-Fori Ghalia, Alan Goodacre, Joanne Horton, Stergios Leventis, Paulo M.D.C. Parente, Mike Smith, Ian Tonks, Anthony Wood, the participants of the 2010 British Accounting Association Annual Conference (Cardiff, UK, March 2010), the $33^{\text {rd }}$ Annual Congress of the European Accounting Association (Istanbul, Turkey, May 2010), the $14^{\text {th }}$ Financial Reporting and Business Communication Conference (Bristol, UK, July 2010) and the 6th workshop on European Financial Reporting (Stirling, UK 2010).

${ }^{a}$ XFi Centre for Finance and Investment, University of Exeter, EX4 4PU, UK

${ }^{\mathrm{b}}$ Accounting and Finance Division, Stirling Management School, The University of Stirling, FK9 4LA, UK

${ }^{*}$ Corresponding author. E-mail: ft222@exeter.ac.uk 


\begin{abstract}
Following IFRS mandatory adoption in 2005, the criteria determining the accounting treatment of R\&D expenditure have changed for UK listed companies that publish consolidated financial statements. Therefore, recent literature raises concerns about the value relevance of R\&D assets and expenses in the UK, after 2005. Using very recent data, we respond to these calls for research. Adding to the absence of prior evidence regarding the pre-IFRS period, we find that the capitalised portion of R\&D is significantly positively related to market values, suggesting that the market perceives these items as successful projects with future economic benefits. R\&D expenses are significantly negatively related to market values under IFRS, supporting the proposition that they reflect no future economic benefits and thus they should be expensed. Also in contrast with evidence regarding the pre-IFRS period, R\&D expenses are negatively value relevant only for large companies. Accordingly, we argue that transition to IFRS does have implications on the valuation of $R \& D$ expenditure in the UK.
\end{abstract}




\section{Introduction}

Depending on the accounting standards in place, Research and Development (R\&D) expenditure can either be expensed as incurred as a whole or partly capitalised and partly expensed. The rationale behind the capitalisation is that significant future economic benefits are expected to be generated, meeting the criteria for asset recognition (Lev et al., 2002). The rationale for charging the $R \& D$ expenditure to the income statement is that such benefits are rather uncertain.

UK General Accepted Accounting Principles (GAAP) permits the capitalisation of certain R\&D expenditure. More specifically, the Statement of Standard Accounting Practice (SSAP) 13, Accounting for Research and Development, provides discretion with regard to capitalisation of certain $R \& D$ expenditure when the recognition criteria are met (paragraph 25). However, it is noted that, since 2005, all European Union (EU) publicly traded firms are required to prepare consolidated accounts under International Financial Reporting Standards $(\text { IFRS })^{1}$ and as a consequence the requirements of IAS 38 Intangibles Assets should be followed instead.

The requirements of IAS 38 for the capitalisation of R\&D expenditure are generally similar with those of the UK GAAP with only one subtle but important difference. Capitalisation of certain $R \& D$ expenditure is a result of the standard's requirements and not management's matter of choice. The exercise of discretion to capitalise certain R\&D expenditure is constrained. In contrast, if a series of specific criteria are met, a company should capitalise the R\&D expenditure as an asset.

This difference is expected to result in significant valuation implications because capitalisation of R\&D in the UK was rare prior to 2005 (Green et al., 1996;

\footnotetext{
${ }^{1}$ In some jurisdictions (e.g. Greece and Italy), this requirement applies also to listed companies which publish only individual accounts.
} 
Stark and Thomas, 1998; Oswald, 2008). Considering this, along with evidence from Australia (cf. Wyatt, 2008), Stark (2008, p. 279) argues that ' ... the IAS, in removing discretion over the treatment of development expenditures, remove a useful way for firms to communicate information to the stock markets' (with reference to the findings of Oswald (2008), see below).

Following along these lines, the first objective of this paper is to examine whether the R\&D reported assets and expenses are value relevant after the adoption of IFRS in the UK. Further, in contrast with evidence from the US, Shah et al. (2008, p. 90) indicate that prior to 2005 there was 'no clear-cut size [valuation] advantage of large firms over small firms’ as far as R\&D was concerned in the UK. Therefore, our second objective is to examine any size-related valuation consequences of $R \& D$ after IFRS mandatory implementation in the UK.

To pursue these objectives, we use recent data by focusing on the financial years 2005 to 2007 of companies with R\&D activity, as this is indicated in the 2006, 2007, and 2008 'R\&D Scoreboards'. ${ }^{2}$ We do find that the capitalised portion of R\&D is positively related to market values, with no significant differences across large and small firms. We also find that the expensed portion of R\&D is negatively related to market values. Yet, this finding is applicable to large companies only.

On that basis, we contribute to the existing literature by adding an empirical study examining the value relevance of $R \& D$ assets and expenses after the mandatory transition to IFRS in the UK, where companies are required to assess whether the capitalisation criteria are met compared to the discretion available in the past. To the best of our knowledge this is the first study to address this issue.

The remainder of the paper is organised as follows. Section II provides the

\footnotetext{
2 The Scoreboards were published by the Department of Innovation, University and Skills (hereafter DIUS; currently named as Department for Business Innovation and Skills). The 2009 Scoreboard had not been published at the time of data collection.
} 
background to the accounting of $R \& D$ expenditure in the UK over the last 30 years and reviews prior literature. This discussion leads to the development of the research hypotheses. Section III describes the research design and the data employed. Section IV reports the empirical findings. Section V forms the concluding remarks.

\section{Background and Development of Hypotheses}

$R \& D$ reporting in the UK: UK GAAP vs. IFRS

SSAP 13 was originally issued in $1977^{3}$. While it introduced the requirement for all the expenditure incurred at the research stage to be expensed as incurred, it also introduced the option to capitalise certain $R \& D$ expenditure, providing that certain criteria which indicate the capitalisation of $R \& D$ are met. SSAP 13 was revised in 1989, with no major changes, ${ }^{4}$ and continues to provide an option to capitalise certain $\mathrm{R} \& \mathrm{D}$ expenditure when the recognition criteria are met (paragraph 25).

The criteria for $R \& D$ capitalisation are the following: the project is clearly defined with the related expenditure being separately identifiable; the project is technically viable and commercial viable; adequate resources exist to complete the project; and lastly, all related expenditures are more than covered from the related revenues (paragraph 25). It is notable that, despite the provision of the optional capitalisation, R\&D expenditures were mainly expensed as incurred (Green et al., 1996) and it was rather rare for companies to capitalise any portion of R\&D (Stark and Thomas, 1998; Oswald, 2008).

\footnotetext{
3 It was the outcome of two exposure drafts (ED): ED 14 (1975) and ED 17 (1976). Hope and Gray (1982) as well as Elliot and Elliot (2006, p. 450) discuss the background to SSAP 13.

${ }^{4}$ One of the changes introduced was to recommend companies which meet certain size criteria to disclose R\&D expenditure. In particular, paragraph 19b states that companies are required to disclose the amount expensed by distinguishing the current year's expenditure and the amortised amount from deferred expenditure. This is applicable to all 'public limited companies, or special category companies, or subsidiaries of such companies, or [the companies] which exceed by the multiple of 10 the criteria for defining medium-sized company under Companies Act 1985' (paragraph 20).
} 
However, since 2005, all EU publicly traded firms reporting consolidated financial statements adopted IFRS, with IAS 38 Intangible Assets governing the accounting treatment of intangibles. IAS 38 requires the capitalisation of certain $R \& D$ expenditures which meet the following criteria. In order to capitalise the development costs an enterprise should assess: the technical feasibility of the intangible asset; the intention to complete the asset with the ability to sell (or use) it; the availability of resources, technical or financial, to complete it; the ability to reliably measure the expenditure and the ability to justify that the asset will generate future economic benefits (paragraph 57). Similar to SSAP 13 (1986), research expenditure should be expensed as incurred.

At first glance, it appears that the treatment of $R \& D$ expenditure is very similar under UK GAAP and IFRS. However, there is a subtle but important difference: IFRS requires the capitalisation of the $R \& D$ expenditure meeting the specified criteria, contrary to the UK GAAP which provides an option to capitalise the $R \& D$ expenditure which meets the criteria. Thereby, following the transition to IFRS, management's discretion would be constrained. As a result, several companies would have to capitalise certain R\&D expenditure previously expensed as incurred (cf. Green et al., 1996; Stark and Thomas, 1998; Oswald, 2008).

\section{Literature Review and Hypotheses}

Among the earliest studies to examine the revised SSAP 13 (1989) was that of Green et al. (1996). Using a sample of firms for the period 1990 to 1992, they regress the companies’ market values against book value of equity, R\&D expense and residual income. ${ }^{5}$ Their findings suggest that, on average, the R\&D expense has a positive

\footnotetext{
${ }^{5}$ They measure residual income as earnings before R\&D expense less the product of cost of equity
} 
statistically significant relationship with market values. They interpret this result as the market perceives $R \& D$ expense as a capital expenditure i.e. the market reverses the expensed R\&D.

Further, Stark and Thomas (1998) employ a sample of companies for the period 1990 to 1994. In contrast to Green et al. (1996), they regress companies' market values against earnings before extraordinary and exceptional items (instead of utilising residual income). Nevertheless, their results are similar with those obtained from Green et al. (1996). The R\&D expense is perceived as a capital component (i.e. asset) instead of being treated as any other expense. In a similar vein, although the focus of the study is not on $\mathrm{R} \& \mathrm{D}$ expenditure per se, Akbar and Stark (2003) report results of similar significance with respect to R\&D expense. For the period 1990 to 2001 they report a significantly positive coefficient for R\&D expense. ${ }^{6}$ Focusing almost on the same period (1990 to 1998), Shah et al. (2009) report similar results to Akbar and Stark (2003). Additionally, Shah et al. (2008) examine the value relevance of the R\&D expense focusing on the period 1998 to 2002 and, consistent with the findings of prior research, they find that R\&D expense is positively value relevant.

Contrary, Zhao (2002) focuses only on companies that capitalise a portion of $R \& D$ and examines the value relevance of $R \& D$ reporting in France, Germany, UK and USA for the period 1990 to 1999. The key characteristic of this study is that it examines both the value relevance of $R \& D$ assets and $R \& D$ expenses in the UK. Interestingly, Zhao's (2002) results show that the capitalised portion of R\&D has a negative coefficient, although it is statistically insignificant. This is possibly a result

capital and lagged book value of equity.

${ }^{6}$ The consistent evidence in the UK that R\&D expenses are perceived as capital components is in line with evidence in the US (e.g. Lev and Sougiannis, 1996; Aboody and Lev, 1998; Healy et al., 2002 Lev et al., 2002; Ballester et al., 2003; Xu et al., 2007) and elsewhere (e.g. Han and Manry, 2004). 
of the small proportion of companies capitalising $R \& D$ in the sample under examination (11\%). ${ }^{7}$ Additionally, R\&D expense is negatively value relevant i.e. it has a negative and significant coefficient. ${ }^{8}$

Further, Oswald (2008) examines the value relevance of R\&D by distinguishing the companies which capitalise a portion of the $R \& D$ expenditure ('capitalisers') from those expensing all the related expenditure ('expensers'). It is worth noting that similar to Zhao (2002) only a small portion of the sample employed consists of 'capitalisers' (approximately 14.5\%) which is consistent with the evidence of the prior literature (cf. Green et al., 1996; Stark and Thomas, 1998; Zhao, 2002). ${ }^{9}$ After adjusting 'capitalisers' to as if 'expensers' and 'expensers' to as if 'capitalisers', he compares the value relevance for both actual and adjusted figures for the two groups separately. He finds that for both groups the value relevance of adjusted figures is not significantly different from the value relevance of the actual figures. For this reason, Oswald (2008) concludes that 'managers choose the correct method for accounting for R\&D’ (ibid, p. 22).

Drawing on the above summary of findings, evidence with respect to the value relevance of $R \& D$ reporting in the $U K$ is limited to $R \& D$ expense. This is, presumably, because of the discretion provided to companies by SSAP 13 to capitalise certain R\&D expenditure, resulting in capitalisation in the UK to be rare. The fact that capitalisation is rare explains the evidence in the prior literature that $R \& D$ expense is treated as a capital component (i.e. positive coefficient).

As discussed above, following transition to IFRS, management's discretion

\footnotetext{
${ }^{7}$ Studies in other countries illustrate that the capitalised portion of R\&D is positively value relevant (cf. Han and Manry, 2004; Ahmed and Falk, 2006) consistent with the premise that it represents future economic benefits.

${ }^{8}$ Although this result appears to contradict with prior evidence in the UK as discussed above, this may not be the case. Other studies do not take into consideration the capitalised portion of $R \& D$ which actually reflects expected economic benefits by the companies.

${ }^{9}$ Although the focus of their research is different, Osma and Young (2009) report similar information.
} 
would be constrained and as a result several companies would have to capitalise certain R\&D expenditure previously expensed as incurred (cf. Green et al., 1996; Stark and Thomas, 1998; Oswald, 2008). Considering the conclusion of Oswald (2008, p. 22) (i.e. that 'managers choose the correct method for accounting for R\&D'), it is argued that the adoption of IAS 38 would remove a useful way companies use to communicate information (Stark, 2008). This argument is in line with Wyatt (2008) who suggests that giving management discretion 'might facilitate more value relevant information on intangibles' (ibid, p. 217). On that basis, one would expect implications in companies' valuations because of the valuation of the $R \& D$ assets and expenses following the transition to IFRS.

As a consequence, we perceive these arguments as a call for research of the subject matter. Hence, we explore the value relevance of the capitalised and the expensed portions of $R \& D$ (i.e. $R \& D$ assets and $R \& D$ expenses), separately. Considering that $\mathrm{R} \& \mathrm{D}$ expenses were treated as capital components in the UK (i.e. positively related to market values) in the past as well as the premise that assets are expected to bring future economic benefits, we expect that the capitalised portion of R\&D has a positive relationship with market values. Instead, what remains as an expensed item should be negatively related to market values. ${ }^{10}$ Therefore, we test the following hypothesis:

H1: The capitalised as well as the expensed portions of $R \& D$ expenditure are value relevant in the UK, after 2005. (A positive (negative) and significant association between capitalized (expensed) R\&D and market values is

\footnotetext{
${ }^{10}$ Cazavan and Jeanjean (2006) argue that in the French context where capitalisation was optional (such as in the UK prior to 2005), R\&D expense contained both unsuccessful and successful projects (due to the optional capitalisation). Moreover, the sign of $R \& D$ expense can 'be negative or positive depending on the relative magnitude of unsuccessful and successful projects' (ibid, p. 53). In the UK context after IFRS adoption, R\&D expense would include unsuccessful projects (i.e. expenses unlikely to bring future economic benefits), therefore, resulting in a negative coefficient.
} 
expected.)

Moreover, it is believed that large companies generate a larger portion of technological advancement (i.e. innovation) due to their size (cf. Cohen and Klepper, 1992; Shah et al., 2008). Further, large firms are more effective in differentiating products or product lines with higher quality of innovations compared to smaller firms. Consistent with the above arguments, US studies (Chauvin and Hirschey, 1993; Connolly and Hirschey, 2005) have indicated that firm size affects valuation. In particular, the effect of $R \& D$ on company value is greater for large firms over small firms suggesting size advantages regarding valuation, as a result of $R \& D$ expenditure. Against expectations, prior research in the UK reports no valuation differences of R\&D for small and big firms (Shah et al., 2008; Shah et al., 2009).

However, it is reminded that prior research is limited to valuation differences of $R \& D$ expenditure only, since capitalisation of $R \& D$ was rare in the UK prior to 2005. On that basis, the actual amount that could be treated as an asset was not explicitly obvious to the users of the financial statements, limiting the illustration of the comparative advantage of large firms with regard to this issue. In fact, we argue that, because under IFRS the actual amount should be treated as a capital component becomes apparent in the financial statements (i.e. the expenditure meeting the criteria for capitalisation is actually capitalised rather than being included in the expensed portion), the valuation differences across large versus small companies will be significant. In particular, we expect any valuation implications of the capitalised as well as the expensed portions of $\mathrm{R} \& \mathrm{D}$ to be more prominent for large companies. Therefore, we test the following hypothesis:

H2: There are different valuation effects of the $R \& D$ reporting between large and small companies in the UK, after 2005. (More (less) significant valuation 
effects are expected for large (small) companies.)

\section{Methodology and Data}

\section{Methodology}

A number in companies' financial statements is deemed to be 'value relevant' if it is significantly related to its market value (Beaver, 2002). Following prior research (e.g. Shah et al., 2008; Oswald, 2008; Shah et al., 2009), in order to examine the value relevance of accounting information, we employ regression analysis by empirically implementing a theoretical extension of the fundamental Ohlson (1995) model where the market value of a firm can be expressed as a linear function of its book value of equity and net income. In its simple form, the model is as follows:

$$
M V E_{i t}=a_{0}+a_{1} B V E_{i t}+a_{2} N I_{i t}+\varepsilon_{i t}
$$

where:

o $\quad M V E_{i t}$ is the market value of equity measured for the company $i$;

o $B V E_{i t}$ is the book value of equity for company $i$ for the respective year of observation $(t)$;

o $\quad N I_{i t}$ is the net income for company $i$ for the respective year of observation $(t)$;

o $\quad \varepsilon_{i t}$ is the mean zero disturbance term;

Easton (1999, p. 402) highlights that one of the main advantages of the model is that 'it forms a framework for understanding the relationship between prices and accounting data'. Another major advantage of this model is that the book value of equity and net income can be decomposed across different components, and hence examine the value relevance of individual items from a company's financial statements, i.e. whether a particular accounting amount assists investors to value a company (Barth et al., 2001).

On that basis and following prior research (Zhao, 2002; Han and Manry, 2004 
Ahmed and Falk, 2006; Cazavan-Jeny and Jeanjean, 2006), we decompose BVE across the BVE before the capitalisation of R\&D (hereafter ABVE) and the R\&D assets (hereafter CapRD). Additionally, we decompose NI across the R\&D expenses (hereafter ExpRD) and income before charging the R\&D expenses (hereafter ANI). This results in Model (2). The coefficients of interest in this function are $b 2$ and $b 4$ :

$$
M V E_{i, t+3}=b_{0}+b_{1} A B V E_{i t}+b_{2} \operatorname{CapRD}_{i t}+b_{3} A N I_{i t}+b_{4} \operatorname{ExpRD}_{i t}+\varepsilon_{i t}
$$

where:

o $\quad M V E_{i, t+3}$ is the market value of equity measured three months after the year end for the company $i ;^{11}$

o $A B V E_{i t}$ is the adjusted book value of equity for company $i$ for the respective year of observation $(t)$, excluding the capitalised $R \& D$ investment;

o $\operatorname{CapRD}_{i t}$ is the capitalised $\mathrm{R} \& \mathrm{D}$ amount, for company $i$ for the respective year of observation $(t)$;

o $A N I_{i t}$ is the adjusted earnings for company $i$ for the respective year of observation $(t)$, prior the R\&D expense;

o $\operatorname{ExpRD}_{i t}$ is the $\mathrm{R} \& \mathrm{D}$ expense, for company $i$ for the respective year of observation $(t)$;

o $\quad \varepsilon_{i t}$ is the mean zero disturbance term;

In order to address the second hypothesis, the sample is partitioned across the subsamples of large and small companies. As a benchmark for size, companies’ median market value with reference to the latest year of examination is used. Then, equation 2 is run separately for each sub-sample. Additionally, similar to Shah et al. (2009), we introduce a dummy variable differentiating large from small companies in equation 2. This results in Equation (3) below. The coefficients of interest in this function are $b 5$ and $b 9$ :

\footnotetext{
${ }^{11}$ This ensures that the accounting information is in the public domain for some period and thus it has been 'absorbed' by investors (cf. Barth et al., 2008; Francis et al., 2004; Harris and Muller, 1999).
} 


$$
\begin{aligned}
& M V E_{i, t+3}=b_{0}+b_{1} S+b_{2} A B V E_{i t}+b_{3} A B V E_{i t} * S+b_{4} \operatorname{CapRD}_{i t}+b_{5} \operatorname{CapRD}_{i t} * S \\
& +b_{6} A N I_{i t}+b_{7} A N I_{i t} * S+b_{8} \operatorname{ExpRD}_{i t}+b_{9} \operatorname{ExpRD}_{i t} * S+\varepsilon_{i t}
\end{aligned}
$$

where:

o $\quad M V E_{i, t+3}$ is the market value of equity measured three months after the year end for the company $i$;

o $\quad \mathrm{S}=1$ if the company is classified as large and $=0$ otherwise;

o $A B V E_{i t}$ is the adjusted book value of equity for company $i$ for the respective year of observation $(t)$, excluding the capitalised $R \& D$ investment;

o $A B V E_{i t} * S$ is the adjusted book value of equity multiplied by the dummy variable

o $\quad \operatorname{CapRD}_{i t}$ is the capitalised $\mathrm{R} \& \mathrm{D}$ amount, for company $i$ for the respective year of observation $(t)$;

o $\quad \operatorname{CapRD}_{i t} * S$ is the capitalised portion of $\mathrm{R} \& \mathrm{D}$ multiplied by the dummy variable

o $A N I_{i t}$ is the adjusted earnings for company $i$ for the respective year of observation ( $t$ ), prior the $R \& D$ expense;

$0 \quad A_{i t} * S$ is the adjusted earnings multiplied by the dummy variable

o $\operatorname{ExpRD}_{i t}$ is the $\mathrm{R} \& \mathrm{D}$ expense, for company $i$ for the respective year of observation $(t)$;

o $\quad \operatorname{ExpRD} D_{i t} * S$ is the R\&D expense multiplied by the dummy variable

o $\varepsilon_{i t}$ is the mean zero disturbance term;

In order to control the models for heteroscedasticity, the 'Heteroscedasticityconsistent covariance matrix estimator 3' (HC3) is employed. This method is suggested by McKinnon and White (1985) as producing more conservative confidence intervals than the basic method suggested by White (1980) and thus generating better results.

For further reducing the possibility of heteroscedasticity the variables of the regression have been deflated by the number of shares (Barth and Clinch, 2009). The use of this deflator is consistent with the findings of Barth and Kallapur (1996) and Barth and Clinch (2009) suggesting that the number of outstanding shares is an effective proxy to capture the effect of scale. (As an alternative approach, we have also used the non deflated specification and the findings are economically similar.) 
Moreover, we have also considered the issue of outliers by defining and excluding as outliers cases for which the standardised residuals lie outside the range of +/-2 standard deviations (Belsley et al., 1980). Finally, as we pool three years of data, we estimate all equations by clustering by year and industry (Petersen, 2009) to account for variations across the years and industries under examination (see below).

Data

In order to undertake the research, firms with ' $R \& D$ activity' should be identified. To identify such activity, we use the 2006 to 2008 UK R\&D Scoreboards. The UK R\&D Scoreboard is prepared annually by ranking the top 850 listed and non-listed companies (top 800 companies for 2006) undertaking R\&D investment in the year before it gets published (DIUS, 2008).

In order to perform the analyses, we exclude all the non-listed firms and all the firms listed in the AIM market. Therefore, the initial number of FTSE listed companies that are featured in the Scoreboards for the three years under examination is 726 firm year observations (311 firms). From those, 418 firm year observations have been used. ${ }^{12}$ This sample consists of 214 observations with no R\&D asset (i.e. expensers) and 204 observations with R\&D asset (i.e. capitalisers). This provides a comparative advantage of our study over prior research as a large number of the companies examined do capitalise $R \& D$ expenditure, allowing for statistically robust analyses regarding the capitalised portion of $R \& D$. Table 1 below summarises the selection procedure of the sample.

\section{TABLE 1 - ABOUT HERE}

\footnotetext{
${ }^{12} 83$ observations regarding 2005, 169 observations regarding 2006 and 166 observations regarding 2007.
} 
Table 2 below details the number of observations across different industries (following the ICB industry classification) as well as the number of observations which are classified as 'capitalisers' and 'expensers'. From this table, it becomes apparent that our sample is mainly consisted of firms in the 'Industrials', 'Technology' and 'Healthcare’ industries.

\section{TABLE 2 - ABOUT HERE}

Financial data are collected from Datastream and directly from the companies' annual reports. More specifically, net income (NI) is the net income available to common equity defined as net income to calculate earnings per share (Worldscope item 01751). The book value of equity (BVE) is the common equity defined as the

shareholders' investment in a company (Worldscope item 03501). R\&D expense is a Worldscope item (item 01201). Finally, considering that R\&D asset in Worldscope is reported along with brands patents and other intangibles under the item 'other intangible assets', the R\&D asset was hand collected from the companies' annual reports for the respective year of observation.

Tables 3 and 4 report the descriptive statistics for the full sample and the subsamples with regard to the variables used in this research.

\section{TABLE 3 - ABOUT HERE}

TABLE 4 - ABOUT HERE

What really stands out from these descriptive statistics is that, relative to their size (i.e. scaled by the number of shares outstanding), large and small companies do 
not invest significantly different amounts for R\&D as one would expect (Chauvin and Hirschey, 1993). In fact, there is weak evidence that the capitalised portion of development expenditure is, on average, larger for small companies. Similar weak evidence is provided with regard to the amount expensed (judging by the median value). Although not tabulated, when deflating all variables by the value of total assets, the results are even more significant. Both the capitalised and the expensed portion of R\&D are significantly larger for smaller firms (at 1\%, both for the mean and the median values).

\section{Results and Discussion}

The results of all tests are presented in Table 5. The findings regarding model (1) are consistent with prior research which examined the value relevance of accounting information in the UK prior to 2005 (e.g. King and Langli, 1998; Arce and Mora, 2002). They indicate that accounting numbers in the UK have strong relationship with share prices (i.e., $\mathrm{R}^{2}$ is relatively high), the coefficient of book value of equity is close to its theoretical value (1) and the coefficient of net income is much higher.

Moving into the results with regard to the decomposed model (2) for the pooled sample, as far as the variables of interest are concerned, it can be seen that the coefficient of CapRD is positive (3.280) and statistically significant at $1 \%$ level. Hence, it can be concluded that, consistent with our expectations, $R \& D$ asset is positively value relevant.

This finding illustrates that investors perceive the capitalised portion of R\&D expenditure as an asset with expected economic benefits when companies report under IFRS. Although this finding is consistent with prior research examining the value relevance of $R \& D$ either based on adjusted accounting figures (Lev and 
Sougiannis, 1996; Healy et al., 2002; Lev et al., 2002) or actual accounting figures (Aboody and Lev, 1998; Zhao, 2002; Han and Manry, 2004; Ahmed and Falk, 2006) in other countries, it contradicts with the findings of Zhao (2002) who reports insignificant coefficients for the capitalised R\&D portion by UK companies prior to 2005. However, it is reminded that Zhao's (2002) study was the only one to consider $R \& D$ assets separately from $R \& D$ expenses for UK companies prior to 2005. This, and the fact that very few companies capitalised R\&D expenditure before 2005, indicates that our knowledge regarding the value relevance of capitalised $R \& D$ reporting prior to 2005 was limited.

Hence, it can be argued that the adoption of IFRS in the UK was not 'a step in the wrong direction' (cf. Ahmed and Falk, 2006, p. 238) since the reported R\&D asset is (positively) value relevant under IFRS, In fact, it could be argued that this finding is in line with the expectations of Barth et al. (2008) and Ball (2006) that IFRS better reflect companies' fundamentals and rejects the argument that the adoption of IFRS would hinder the value relevance of R\&D reporting (cf. Stark, 2008 and Wyatt, 2008).

Focusing on the expensed portion of R\&D (i.e. ExpRD), it can be seen that it is also statistically significant at $1 \%$ level but with a negative coefficient (-6.243), suggesting that the $R \& D$ expenses are negatively value relevant. This result is consistent with prior research (Zhao, 2002 (UK); Cazavan-Jeny and Jeanjean; 2006 (France)) suggesting that the $R \& D$ expense is perceived by the market as unsuccessful projects with no economic benefits, contrary to the capitalised R\&D portion.

On that basis, our first hypothesis is supported. The capitalised as well as the expensed portions of $R \& D$ expenditure are positively and negatively value relevant 
respectively in the UK, after 2005.

\section{TABLE 5 - ABOUT HERE}

The results with reference to the sub-samples, as presented in Table 5, shed more light with regard to our second hypothesis. More specifically, for both small and large companies, the coefficient of capitalised R\&D is positive and significant (2.123 and 4.973 respectively, at $10 \%$ ). However, the difference between these two coefficients (2.850) is not significant. In contrast, the coefficient of $R \& D$ expenditure is significant only for large companies (at 1\%). Additionally, it is significantly (at 1\%) lower (by 9.396) than the corresponding coefficient of small companies.

As robustness checks, we have also conducted all our analyses by following two steps regressions ${ }^{13}$ by introducing lagged market values, book-to-market and the percentage of foreign sales as instrumental variables. All the results are economically similar with exception being the results for model 3. In particular, we find the same signs for the differences in the coefficients of the capitalised and the expensed portion of R\&D of both groups. However, we find significant the difference for the capitalised portion of $R \& D$ (at 10\%) and insignificant the difference for the expensed portion.

On that basis, we conclude that after the mandatory implementation of IFRS there are differences in the valuation of UK companies, with regard to R\&D reporting because the expensed portion of $R \& D$ is consistently negatively value relevant only for large firms. This contrasts the findings of Shah et al. (2008) who

\footnotetext{
${ }^{13}$ We thank and anonymous reviewer for this suggestion.
} 
find that R\&D expense was significant (and positive) for both large and small companies prior to 2005. Nevertheless, in line with Shah et al. (2008), even after the adoption of IFRS, there is still no clear difference in the coefficients of this variable across the two sub-samples. Therefore, we conclude that the there is partial support for our second hypothesis.

We argue that finding the $R \& D$ expense being negatively value relevant only for large firms, is a result of the adoption of IFRS which set more constraints on managers' discretion regarding the capitalisation of the development expenditure. IFRS provide a clearer picture to investors on whether the research expenditure really constitutes expenditures on unsuccessful projects that will bring no future benefits to the company. As a result, investors can form better conclusions on whether the amounts spent on R\&D are efficiently spent (i.e. if they are actually capitalised).

More specifically, investors may expect larger companies to make more efficient use of the research expenditure because of economies of scale and scope (Chauvin and Hirschey, 1993) and to generate a larger portion of technological advancement (i.e. innovation) due to their size (cf. Cohen and Klepper, 1992; Shah et al., 2008). This would suggest size advantages with regard to their valuation as well. However, the descriptive statistics presented in table 4 indicate that, at least for our sample, there is no clear evidence that large companies invest and, as a result, capitalise more development expenditure, relative to their size. This results in the research expenditure to have negative effects on large companies' market values only. This is interpreted as the large companies not having a valuation advantage because of the R\&D they engage with. 


\section{Conclusion}

The subtle differences between UK GAAP and IFRS regarding the accounting treatment of R\&D expenditure, along with evidence from Australia (cf. Wyatt, 2008), have raised concerns with regard to the valuation implications of R\&D reporting in the UK after 2005 (cf. Stark, 2008). Further, in contrast with evidence from the US, recent literature indicates that prior to 2005 there was 'no clear-cut size [valuation] advantage of large firms over small firms' as far as R\&D was concerned in the UK (Shah et al., 2008, p. 90). Following along these lines, the present study examined whether the $R \& D$ reported assets and expenses are value relevant after the adoption of IFRS in the UK. Additionally, it examined any size-related valuation consequences of R\&D after IFRS mandatory implementation in the UK.

First, we find that, against the concerns that the adoption of IFRS may lead to less value relevant $R \& D$ reporting in the UK, during the first three years of IFRS mandatory implementation, the capitalised portion of R\&D expenditure is positively value relevant. This was not the case under UK GAAP (cf. Zhao, 2002). Second, in contrast to the findings of Shah et al. (2008) regarding the pre-IFRS period, following the transition to IFRS there are size related valuation differences with reference to $R \& D$ expenditure in the UK. The expensed portion of $R \& D$ is significantly value relevant only for large companies.

Considering our findings, we conclude that there is evidence supporting the expectations of Barth et al. (2008) and Ball (2006) that IFRS better reflect companies’ fundamentals. It remains an open path for future research to illustrate whether similar valuation implications, with regard to R\&D reporting, hold in other countries where IFRS introduced different accounting treatment of the subject matter compared to the previously followed accounting regulations. 


\section{References}

Aboody, D. and Lev, B. (1998) The value relevance of intangibles: The case of software capitalization, Journal of Accounting Research, 36, 161-191.

Ahmed, K. and Falk, H. (2006) The value relevance of management research and development reporting choice: Evidence from Australia, Journal of Accounting and Public Policy, 25, 231-264.

Akbar, S. and Stark, A. W. (2003) Deflators, net shareholder cash flows, dividends, capital contributions and estimated models of corporate valuation, Journal of Business Finance and Accounting, 30, 1211-1233.

Arce, M. and Mora, A. (2002) Empirical evidence of the effect of European accounting differences on the stock market valuation of earnings and book value, European Accounting Review, 11, 573-599.

Ball, R. (2006) International financial reporting standards (IFRS): Pros and cons for investors, Accounting and Business Research, 36, 5-27.

Ballester, M., Garcia-Ayuso, M. and Livnat, J. (2003) The economic value of the R\&D intangible asset, European Accounting Review, 12, 605-633.

Barth, M. E., Beaver, W. H. and Landsman, W. R. (2001) The relevance of the value relevance literature for financial accounting standard setting: Another view, Journal of Accounting and Economics, 31, 77-104.

Barth, M. E. and Clinch, G. (2009) Scale effects in capital markets-based accounting research, Journal of Business Finance and Accounting, 36, 253-288.

Barth, M. E. and Kallapur, S. (1996) The effects of cross-sectional scale differences on regression results in empirical accounting research, Contemporary Accounting Research, 13, 527-567.

Barth, M. E., Landsman, W. R. and Lang, M. H. (2008) International accounting standards and accounting quality, Journal of Accounting Research, 46, 467498.

Beaver, W. H. (2002) Perspectives on recent capital market research. The Accounting Review, 77, 453-474.

Cazavan-Jeny, A. and Jeanjean, T. (2006) The negative impact of R\&D capitalization: A value relevance approach, European Accounting Review, 15, 37-61.

Chauvin, K. W. and Hirschey, M. (1993) Advertising, R\&D expenditures and the market value of the firm, Financial Management, 22, 128-140.

Cohen, W. M. and Klepper, S. (1992) The anatomy of industry R\&D intensity distributions, American Economic Review, 82, 773-799.

Connolly, R. A. and Hirschey, M. (2005) Firm size and the effect of R\&D on Tobin's q, $R \& D$ Management, 35, 217-223.

Department for Innovation, Universities and Skills, 2006, The 2006 R\&D scoreboard, Available at:

http://www.innovation.gov.uk/rd_scoreboard/downloads/2006_rd_scoreboard_data.p df [Accessed at: 25/06/09]

Department for Innovation, Universities and Skills, 2007, The 2007 R\&D scoreboard, Available at:

http://www.innovation.gov.uk/rd_scoreboard/downloads/2007_rd_scoreboard_data.p df [Accessed at: 25/06/09]

Department for Innovation, Universities and Skills, 2008, The 2008 R\&D scoreboard, Available at: 
http://www.innovation.gov.uk/rd_scoreboard/downloads/2008_RD_Scoreboard_data .pdf [Accessed at: 25/06/09]

Belsley, D. A. Kuh, E. and Welsch, R. E. 1980, Regression diagnostics, Wiley, New York, NY

Elliot B. and Elliot J., 2006, Financial Accounting and Reporting, $12^{\text {th }}$ Ed., Financial Times Prentice Hall: London

Easton, P. D. (1999) Security returns and the value relevance of accounting data, Accounting Horizons, 13, 399-412.

Francis, J., Lafond, R., Olsson, P. M. and Schipper, K. (2004) Costs of equity and earnings attributes, Accounting Review, 79, 967-1010.

Green, J. P., Stark, A. W. and Thomas, H. M. (1996) UK evidence on the market valuation of research and development expenditures, Journal of Business Finance and Accounting, 23, 191-216.

Han, B. H. and Manry, D. (2004) The value-relevance of R\&D and advertising expenditures: Evidence from Korea, The International Journal of Accounting, 39, 155-173.

Harris, M. S. and Muller III, K. A. (1999) The market valuation of IAS versus USGAAP accounting measures using form 20-F reconciliations, Journal of Accounting \& Economics, 26, 285-312.

Healy, P. M., Myers, S. C. and Howe, C. D. (2002) R\&D accounting and the tradeoff between relevance and objectivity, Journal of Accounting Research, 40, 677710.

Hope, T. and Gray, R. (1982) Power and policy making: The development of an R\&D standard, Journal of Business Finance and Accounting, 9, 531-558.

King, R. D. and Langli, J. C. (1998) Accounting diversity and firm valuation, International Journal of Accounting, 33, 529-567.

Lev., B., Nissim, D. and Thomas, J. (2002) On the informational usefulness of R\&D capitalization and amortization, as cited from the book: Zambon, S., Marzo, G., 2007, Visualising Intangibles: Measuring and Reporting in the Knowledge Economy, Ashgate Publishing Limited

Lev, B. and Sougiannis, T. (1996) The capitalization, amortization, and value relevance of R\&D, Journal of Accounting and Economics, 21, 107-138.

Mackinnon, J. G. and White, H. (1985) Some heteroskedasticity-consistent covariance matrix estimators with improved finite sample properties, Journal of Econometrics, 29, 305-325.

Ohlson, J. A. (1995) Earnings, book values, and dividends in equity valuation, Contemporary Accounting Research, 11, 661-687.

Osma, B. G. and Young, S. (2009) R\&D expenditure and earnings targets, European Accounting Review, 18, 7-32.

Oswald, D. R. (2008) The determinants and value relevance of the choice of accounting for research and development expenditures in the United Kingdom, Journal of Business Finance and Accounting, 35, 1-24.

Petersen, M. A. (2009) Estimating standard errors in finance panel data sets: Comparing approaches, Review of Financial Studies, 22, 435-480.

Shah, S. Z. A., Stark, A. W. and Akbar, S. (2008) Firm size, sector and market valuation of R\&D expenditures, Applied Financial Economics Letters, 4, 8791.

Shah, S. Z. A., Stark, A. W. and Akbar, S. (2009) The value relevance of major media advertising expenditures: Some UK Evidence, International Journal of Accounting, 44, 187-206. 
Stark, A. W. (2008) Intangibles and research - an overview with a specific focus on the UK, Accounting and Business Research, 38, 275-285.

Stark, A. W. and Thomas, H. M. (1998) On the empirical relationship between market value and residual income in the UK, Management Accounting Research, 9, 445-460.

White, H. (1980) A heteroskedasticity-consistent covariance matrix estimator and a direct test for heteroskedasticity, Econometrica, 48, 817-838.

Wyatt, A. (2008) What financial and non-financial information on intangibles is value relevant? A review of the evidence, Accounting and Business Research, 38, 217-256.

Xu, B., Magnan, M. L. and Andre, P. E. (2007) The stock market valuation of R\&D information in biotech firms, Contemporary Accounting Research, 24, 12911318.

Zhao, R. (2002) Relative value relevance of R\&D reporting: An international comparison, Journal of International Financial Management and Accounting, 13, 153-174. 
Table 1: Sample observations

\begin{tabular}{|l|r|}
\hline & No. of Observations \\
\hline Observations identified in the Scoreboards & 2,500 \\
Observations of unlisted firms & $(1,316)$ \\
Observations of AIM listed firms & $(457)$ \\
Observations of OFEX listed firms & $(1)$ \\
\hline Observations of FTSE listed firms & 726 \\
Observations of financial companies & $(41)$ \\
Observations of companies not reporting under IFRS* & $(118)$ \\
Observations with missing data & $(149)$ \\
\hline Final sample & 418 \\
& \\
Firm year observations with R\&D asset & 204 \\
Firm year observations with no R\&D asset & 214 \\
\hline
\end{tabular}

*This refers to companies which adopted IFRS for their 2005/2006 financial statements, as a result of their yearend (e.g. end of April, March June etc). This is why we have substantially more observations for 2006.

Table 2: Number of observations for each ICB industry

\begin{tabular}{|l|c|c|c|c|c|c|}
\hline \multicolumn{1}{|c|}{ ICB Industry } & $N$ & Percentage & Capitalisers & Percentage & Expensers & Percentage \\
\hline Oil \& Gas & 7 & $1.67 \%$ & 0 & $0.00 \%$ & 7 & $1.67 \%$ \\
Basic Material & 29 & $6.94 \%$ & 7 & $1.76 \%$ & 22 & $5.26 \%$ \\
Industrials & 146 & $34.93 \%$ & 94 & $22.49 \%$ & 52 & $12.44 \%$ \\
Consumer Goods & 44 & $10.53 \%$ & 15 & $3.59 \%$ & 29 & $6.94 \%$ \\
Health Care & 57 & $13.64 \%$ & 26 & $6.22 \%$ & 31 & $7.42 \%$ \\
Consumer Services & 26 & $6.22 \%$ & 4 & $0.96 \%$ & 22 & $5.26 \%$ \\
Telecommunications & 6 & $1.44 \%$ & 3 & $0.72 \%$ & 3 & $0.72 \%$ \\
Utilities & 14 & $3.35 \%$ & 2 & $0.48 \%$ & 12 & $2.87 \%$ \\
Technology & 89 & $21.29 \%$ & 53 & $12.68 \%$ & 36 & $8.61 \%$ \\
\hline Total & 418 & $100 \%$ & 204 & $48.80 \%$ & 214 & $51.20 \%$ \\
\hline
\end{tabular}

Table 3: Full sample descriptive statistics

\begin{tabular}{|l|c|r|r|r|r|r|}
\hline Variables & $N$ & Mean & Median & \multicolumn{1}{c|}{ SD } & \multicolumn{1}{c|}{ Min } & \multicolumn{1}{c|}{ Max } \\
\hline MVE & 418 & 3.69 & 2.05 & 4.92 & 0.01 & 52.33 \\
BVE & 418 & 1.14 & 0.74 & 1.54 & -1.30 & 12.51 \\
NI & 418 & 0.19 & 0.10 & 0.45 & -1.65 & 3.98 \\
ABVE & 418 & 1.11 & 0.71 & 1.54 & -1.33 & 12.51 \\
CapRD & 418 & 0.03 & 0.00 & 0.07 & 0.00 & 0.78 \\
ANI & 418 & 0.26 & 0.14 & 0.48 & -1.55 & 3.99 \\
ExpRD & 418 & 0.07 & 0.03 & 0.11 & 0.00 & 0.79 \\
\hline NOSH (ml) & 418 & 559 & 151 & 1,170 & 7.10 & 8,330 \\
\hline
\end{tabular}

All variables are deflated by the number of ordinary shares outstanding. MVE is the market value of equity measured three months after the year end, BVE is the book value of equity, NI is the net income, ABVE is the book value of equity excluding the $R \& D$ asset, CapRD is the $R \& D$ asset, ANI is the net income before the $R \& D$ expense, ExpRD is the expensed R\&D and NOSH is the number of ordinary shares. 
Table 4: Descriptive statistics of the sub-samples

\begin{tabular}{|c|c|c|c|c|c|c|c|c|c|c|}
\hline Variables & \multicolumn{2}{|c|}{$N$} & Mean & Median & \multicolumn{2}{|c|}{$S D$} & \multicolumn{2}{|c|}{ Min } & \multicolumn{2}{|c|}{$\operatorname{Max}$} \\
\hline & $\mathbf{L}$ & $\mathrm{S}$ & $\mathbf{L}$ & $\mathbf{L}$ & $\mathbf{L}$ & S & $\mathbf{L}$ & $\mathrm{S}$ & $\mathbf{L}$ & $\mathrm{S}$ \\
\hline $\begin{array}{l}\text { MVE } \\
\text { test of difference }\end{array}$ & 202 & 216 & 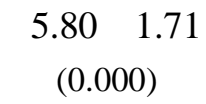 & $\begin{array}{c}4.11 \quad 1.24 \\
(0.000)\end{array}$ & 6.15 & 1.85 & 0.19 & 0.01 & 52.33 & 13.16 \\
\hline $\begin{array}{l}\text { BVE } \\
\text { test of difference }\end{array}$ & 202 & 216 & $\begin{array}{c}1.66 \quad 0.66 \\
(0.000)\end{array}$ & $\begin{array}{c}1.05 \quad 0.48 \\
(0.000)\end{array}$ & 2.00 & 0.60 & -0.37 & -1.30 & 12.51 & 3.07 \\
\hline $\begin{array}{l}\text { NI } \\
\text { test of difference }\end{array}$ & 202 & 216 & $\begin{array}{c}0.37 \quad 0.02 \\
(0.000)\end{array}$ & $\begin{array}{c}0.20 \quad 0.03 \\
(0.000)\end{array}$ & 0.56 & 0.20 & -0.07 & -1.65 & 3.98 & 0.51 \\
\hline $\begin{array}{l}A B V E \\
\text { test of difference }\end{array}$ & 202 & 216 & $\begin{array}{c}1.64 \quad 0.62 \\
(0.000)\end{array}$ & $\begin{array}{c}1.05 \quad 0.46 \\
(0.000)\end{array}$ & 2.00 & 0.59 & -0.37 & -1.33 & 12.51 & 3.07 \\
\hline $\begin{array}{l}\text { CapRD } \\
\text { test of difference }\end{array}$ & 202 & 216 & $\begin{array}{c}0.02 \quad 0.04 \\
(0.064)\end{array}$ & $\begin{array}{c}0.00 \quad 0.00 \\
(0.000)\end{array}$ & 0.07 & 0.07 & 0.00 & 0.00 & 0.78 & 0.41 \\
\hline $\begin{array}{l}\text { ANI } \\
\text { test of difference }\end{array}$ & 202 & 216 & $\begin{array}{c}0.45 \quad 0.09 \\
(0.000)\end{array}$ & $\begin{array}{c}0.26 \quad 0.07 \\
(0.000)\end{array}$ & 0.60 & 0.22 & -0.06 & -1.55 & 3.99 & 0.99 \\
\hline $\begin{array}{l}\text { ExpRD } \\
\text { test of difference }\end{array}$ & 202 & 216 & $\begin{array}{c}0.08 \quad 0.07 \\
(0.282)\end{array}$ & $\begin{array}{c}0.03 \quad 0.04 \\
(0.018)\end{array}$ & 0.14 & 0.08 & 0.00 & 0.00 & 0.79 & 0.63 \\
\hline $\begin{array}{l}\text { NOSH }(\mathrm{ml}) \\
\text { test of difference }\end{array}$ & 202 & 216 & $\begin{array}{c}1,010 \quad 140 \\
(0.000)\end{array}$ & $\begin{array}{c}418 \quad 76.80 \\
(0.000)\end{array}$ & 1,550 & 244 & 32.20 & 7.10 & 8,330 & 2,980 \\
\hline
\end{tabular}

All variables are deflated by the number of ordinary shares outstanding. L represents the large firms whereas $\mathrm{S}$ represents the small firms. Test of difference is based on $t$-tests for the means and on Wilcoxon signed-ranks test for the medians, and their corresponding p-values are shown in brackets.

MVE is the market value of equity measured three months after the year end, BVE is the book value of equity, $\mathrm{NI}$ is the net income, ABVE is the book value of equity excluding the R\&D asset, CapRD is the R\&D asset, ANI is the net income before the R\&D expense, ExpRD is the expensed R\&D and NOSH is the number of ordinary shares. 
Table 5: Value relevance of $R \& D$ in the UK reporting after 2005

\begin{tabular}{|c|c|c|c|c|c|}
\hline & $\begin{array}{r}\text { (2) } M V E_{i, t-} \\
M V E_{i, t+3}=b_{0} \\
+b_{6} A N I_{i t}+b\end{array}$ & $\begin{array}{rl} & M V E_{i t}=a_{0}+ \\
+ & b_{1} A B V E_{i t}+b \\
+ & b_{2} A B V E_{i t}+b \\
* & S+b_{8} \operatorname{ExpRL}\end{array}$ & $\begin{array}{l}3 V E_{i t}+a_{2} N I \\
P R D_{i t}+b_{3} A \\
B V E_{i t} * S+ \\
+b_{9} \operatorname{ExpRD}_{i t}\end{array}$ & $\begin{array}{l}\varepsilon_{i t} \\
I_{i t}+b_{4} \operatorname{ExpRD} \\
\operatorname{CapRD} D_{i t}+b_{5} \\
S+\varepsilon_{i t}\end{array}$ & $D_{i t} * S$ \\
\hline & Poc & nple & Sub & mples & \\
\hline Variables & $\begin{array}{c}\text { Basic } \\
\text { Model (1) }\end{array}$ & $\begin{array}{c}\text { Decomposed } \\
\text { Model (2) }\end{array}$ & $\begin{array}{l}\text { Small } \\
\text { firms }\end{array}$ & $\begin{array}{l}\text { Large } \\
\text { firms }\end{array}$ & (Model 3) \\
\hline Intercept & $0.929 * * *$ & $0.809 * * *$ & 0.558 & $1.065 * * *$ & $0.507 * *$ \\
\hline$B V E$ & $1.031 * * *$ & & & & \\
\hline$N I$ & $7.538 * * *$ & & & & \\
\hline$A B V E$ & & $0.940 * * *$ & $0.957 * * *$ & $0.541 * * *$ & -0.416 \\
\hline CapRD & & $3.280 * * *$ & $2.123^{*}$ & $4.973^{*}$ & 2.850 \\
\hline ANI & & $7.861 * * *$ & $4.480 * * *$ & $10.326^{* * *}$ & $5.846 * * *$ \\
\hline $\operatorname{ExpRD}$ & & $-6.243 * * *$ & -0.695 & $-10.090 * * *$ & $-9.395 * * *$ \\
\hline$F$ & $221.83 * * *$ & $116.30 * * *$ & $189.38 * * *$ & $173.61^{* * *}$ & \\
\hline Adj $R 2$ & 0.72 & 0.73 & 0.54 & 0.77 & \\
\hline$N$ & 378 & 378 & 210 & 168 & \\
\hline
\end{tabular}

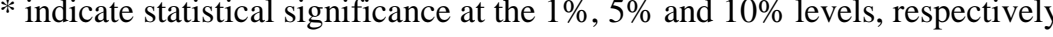

All variables are deflated by the number of ordinary shares outstanding. BVE is the book value of equity, NI is the net income, ABVE is the book value of equity excluding the R\&D asset, CapRD is the R\&D asset, ANI is the net income before the R\&D expense, ExpRD is the expensed $R \& D$ and $S$ is the dummy variable for size: where $\mathrm{S}=1$ if the company is classified as large and $=0$ otherwise. 